\title{
Comparison of Fumonisin Concentrations in Kernels of Transgenic Bt Maize Hybrids and Nontransgenic Hybrids
}

\author{
Gary P. Munkvold, Department of Plant Pathology, Richard L. Hellmich, USDA-ARS Corn Insects and Crop \\ Genetics Research Unit and Department of Entomology, Iowa State University, Ames 50011, and Larry G. Rice, \\ USDA-APHIS National Veterinary Services Laboratory, 1800 Dayton Rd., Ames, IA 50010
}

\begin{abstract}
Munkvold, G. P., Hellmich, R. L., and Rice, L. G. 1999. Comparison of fumonisin concentrations in kernels of transgenic Bt maize hybrids and nontransgenic hybrids. Plant Dis. 83:130138.

Maize hybrids genetically engineered with genes from the bacterium Bacillus thuringiensis (Bt maize) express CryIA(b) and other Cry proteins that are toxic to certain insects, particularly the European corn borer (Ostrinia nubilalis). Maize kernel feeding by $O$. nubilalis often leads to infection by fungi in the genus Fusarium, including the fumonisin-producing species $F$. verticillioides and F. proliferatum. In field experiments in 1995, 1996, and 1997, transgenic maize hybrids and near-isogenic, nontransgenic hybrids were manually infested with neonatal European corn borer larvae. Manual infestation increased Fusarium ear rot severity and fumonisin concentrations in kernels of nontransgenic hybrids. Transgenic hybrids with kernel expression of CryIA(b) consistently experienced less insect feeding on kernels and less Fusarium ear rot than their nontransgenic counterparts. In manually infested treatments, these hybrids also exhibited lower concentrations of fumonisins in kernels compared with their nontransgenic counterparts. In manually infested treatments in 1995 , mean fumonisin $B_{1}$ concentrations were 8.8 $\mu \mathrm{g} / \mathrm{g}$ in the nontransgenic hybrid and 6.7 or $3.0 \mu \mathrm{g} / \mathrm{g}$ in transgenic hybrids. In 1996, mean fumonisin $B_{1}$ concentrations in manually infested treatments were $4.9 \mu \mathrm{g} / \mathrm{g}$ (range 2.3 to 8.8 ) for nontransgenic and $1.2 \mu \mathrm{g} / \mathrm{g}$ (range 1.0 to 1.3 ) for transgenic hybrids with kernel expression. Mean total fumonisin concentrations (fumonisin $\mathrm{B}_{1}+\mathrm{B}_{2}+\mathrm{B}_{3}$ ) were $7.0 \mu \mathrm{g} / \mathrm{g}$ (range 3.0 to 12.2) for nontransgenic and $1.7 \mu \mathrm{g} / \mathrm{g}$ (range 1.5 to 1.9 ) for transgenic hybrids with kernel expression. In 1997, mean fumonisin $B_{1}$ concentrations in manually infested treatments were $11.8 \mu \mathrm{g} / \mathrm{g}$ (range 7.6 to 17.3) for nontransgenic and $1.3 \mu \mathrm{g} / \mathrm{g}$ (range 0.8 to 2.2 ) for transgenic hybrids with kernel expression of CryIA(b) or Cry9C. Mean total fumonisin concentrations were $16.5 \mu \mathrm{g} / \mathrm{g}$ (range 10.7 to 24.0) for nontransgenic and $2.1 \mu \mathrm{g} / \mathrm{g}$ (range 1.5 to 3.1 ) for transgenic hybrids with kernel expression. Transgenic hybrids that do not express CryIA(b) or Cry9C in kernels did not consistently have fumonisin concentrations different from the nontransgenic hybrids. Higher fumonisin concentrations in nontransgenic hybrids were associated with high European corn borer populations during the early reproductive stages of the maize plants. These results indicate that under some conditions, genetic engineering of maize for insect resistance may enhance its safety for animal and human consumption.
\end{abstract}

Additional keywords: corn, Fusarium moniliforme, mycotoxins

Fungi in the genus Fusarium are very common associates of maize (Zea mays L.) plants. These fungi can cause disease at all developmental stages of the plant, but also may infect plants without causing symptoms (24). Certain Fusarium species, particularly $F$. verticillioides (Sacc.) Nirenberg (synonym $=F$. moniliforme J. Sheld.) and $F$. proliferatum (T. Matsushima) Nirenberg, often infect maize plants through wounds caused by insects such as the European corn borer (Ostrinia nubilalis) $(3,24)$. The same two species are capable

Corresponding author: Gary P. Munkvold

E-mail: munkvold@iastate.edu

Accepted for publication 21 October 1998.

Publication no. D-1998-1130-02R

(C) 1999 The American Phytopathological Society insect tunnel into the stalks and ears of the plants, causing yield reduction and loss of grain quality (14). In the north central United States, two generations of ECB larvae typically occur per year; the first generation attacks plants during the mid- to late-vegetative stages (V8-V10 [22]), and the second generation attacks during the reproductive stages ( $\mathrm{R} 1$ to maturity). Adult moths lay masses of eggs on leaf surfaces, and the larvae migrate to protected sites, where they feed on leaves, stalks, and ears (14). These larvae cause physical injury to the plants, where Fusarium infection can occur (3), and the larvae also can carry Fusarium spores from the leaf surface, transmitting them to the infection court (feeding site) (25). A new strategy for the management of $O$. nubilalis is the use of transgenic maize hybrids ( $B t$ maize). Now commercially available, these hybrids contain cry genes originating from the bacterium Bacillus thuringiensis; gene expression results in the production of insecticidal crystalline proteins in plant tissue (8). Currently available commercial hybrids express one of three Cry proteins: CryIA(b), CryIA(c), or Cry9C. Maize hybrids expressing Cry proteins have demonstrated a high level of resistance to feeding by ECB larvae $(2,11)$. Expression of Cry proteins in specific maize tissues can be manipulated through the use of different gene promoters (11). Specific combinations of transgenes and gene promoters are often called "transformation events," and each combination must be approved separately by the U.S. Environmental Protection Agency. The use of these genetically engineered maize hybrids has been widely accepted in the United States but has met opposition elsewhere in the world because of concerns about food safety, environmental protection, and ethical issues.

Transgenic maize hybrids expressing CryIA(b) in kernels can experience less Fusarium infection in kernels because of the association between Fusarium infection and insect feeding (17). We hypothesized these hybrids also might contain lower concentrations of fumonisins than nontransgenic hybrids that are susceptible to the ECB. The objective of this study was to test this hypothesis through field experiments using near-isogenic maize hybrids with and without cry genes. Fusarium infection data from two of 
these experiments have been reported (17).

\section{MATERIALS AND METHODS}

Field experiments were conducted in 1995, 1996, and 1997. In each experiment, transgenic hybrids were compared with near-isogenic, nontransgenic maize hybrids lacking cry genes. Near-isogenic hybrids were supplied by cooperating seed companies and were either identical with (except their corresponding transgenic hybrids. Experiments were arranged in randomized complete block designs in 1995 and 1996; in 1997, a split-plot design was used with hybrids as main plots and infestation treatments as subplots. Plot size differed by $9.15 \mathrm{~m}$ long (approximately 40 plants per row); in 1996, they were four rows by $6.1 \mathrm{~m}$ long (approximately 26 plants per row); and in 1997, main plots were four rows by $3.05 \mathrm{~m}$ long (approximately 15 plants per row) and subplots were single rows. Row spacing was $0.76 \mathrm{~m}$. Only the middle two rows of the four-row plots were treated and analyzed. There were 3.05-m or 1.5-m fallow alleyways between replicate blocks.

The 1995 experiment, planted at the Iowa State University Woodruff Farm in Story County on 22 May, involved three maize hybrids (Table 1) and two O. nubilalis infestation treatments with six replicate blocks. The 1996 experiment, planted on 13 and 14 May at the ISU Johnson for the cry genes) or very closely related to among years: in 1995, plots were four rows

Farm in Story County, included eight hybrids (Table 1) and two $O$. nubilalis infestation treatments with five replicate blocks. The 1997 experiment, planted on 20 May at the ISU Berkey Farm in Boone County, included 12 hybrids (Table 1) and four infestation treatments with 10 replicate blocks.

In 1995 and 1996, the two O. nubilalis infestation treatments were natural infestation and manual infestation. Laboratoryreared ECB larvae for manual infestation were obtained from the USDA Corn Insects Laboratory in Ames, Iowa. Larvae were premixed in ground corn and applied to the plants using a volumetric dispenser that dispenses $1.0-\mathrm{g}$ aliquots of mixture containing 50 neonatal larvae. Manual infestation was conducted by dispensing 50 larvae into the whorl of each plant at growth stage V8-V10 (22) (first generation) and into the axil of the ear leaf at growth stage R1 (second generation). Manual infestation was conducted to reduce plant-to-plant variability in insect feeding and to simulate a uniform infestation throughout the plots. This method and intensity for manual infestation are standard for European corn borer research (7). In 1997, the four infestation treatments were: natural infestation, manual infestation, $F$. verticillioides-contaminated firstgeneration manual infestation (Manual$\mathrm{F} 1)$; and $F$. verticillioides-contaminated second-generation manual infestation (Manual-F2). Larvae for the Manual-F1 treatment were prepared by growing $F$.

Table 1. Transformation events, Cry proteins, and maize hybrids represented in field experiments examining the effects of Cry protein expression on fumonisin concentrations in kernels

\begin{tabular}{|c|c|c|c|c|}
\hline Year & $\begin{array}{c}\text { Transformation } \\
\text { event }\end{array}$ & Cry protein & $\begin{array}{c}\text { Cry protein expression } \\
\text { in all plant tissues }\end{array}$ & Hybrid \\
\hline \multirow[t]{3}{*}{1995} & MON810 & CryIA(b) & Yes & Monsanto $^{\text {u }} 802$ \\
\hline & MON810 & CryIA(b) & Yes & Monsanto $^{\mathrm{u}} 810$ \\
\hline & None & None & $\ldots$ & $\mathrm{B} 73 \times \mathrm{Mo} 17$ \\
\hline \multirow[t]{8}{*}{1996} & MON810 & CryIA(b) & Yes & Monsanto $^{\mathrm{u}} 810$ \\
\hline & None & None & & $\mathrm{B} 73 \times \mathrm{Mo} 17$ \\
\hline & BT11 & CryIA(b) & Yes & Northrup King ${ }^{v}$ X6534CBR \\
\hline & None & None & & Northrup King $^{v}$ N6800 \\
\hline & 176 & CryIA(b) & No & Mycogen ${ }^{w}$ NG7059BT \\
\hline & None & None & $\ldots$ & Mycogen $^{w} 7050 \mathrm{cb}^{\mathrm{x}}$ \\
\hline & 176 & CryIA(b) & No & $\mathrm{Ciba}^{\vee} \mathrm{MAX} 454$ \\
\hline & None & None & & $\mathrm{Ciba}^{\mathrm{v}} 4494$ \\
\hline \multirow[t]{12}{*}{1997} & MON810 & CryIA(b) & Yes & Pioneer $^{x}$ hybrid 34R06 \\
\hline & None & None & & Pioneer ${ }^{x}$ hybrid 3489 \\
\hline & Bt11 & CryIA(b) & Yes & Novartis $^{v}$ NK 7070BT \\
\hline & None & None & $\ldots$ & Novartis ${ }^{v}$ NK 7070 \\
\hline & 176 & CryIA(b) & No & Mycogen ${ }^{w}$ NG 7059 \\
\hline & None & None & $\ldots$ & Mycogen $^{w} 7059 \mathrm{cb}^{\mathrm{x}}$ \\
\hline & 176 & CryIA(b) & No & $\mathrm{Ciba}^{v} \mathrm{Max} 454$ \\
\hline & None & None & $\ldots$ & $\mathrm{Ciba}^{\mathrm{v}} 4494$ \\
\hline & DBT418 & CryIA(c) & Yes & DeKalby $^{580 B T}$ \\
\hline & None & None & & DeKalb $^{y} 580$ \\
\hline & CBH351 & Cry9C & Yes & $\mathrm{AgrEvo}^{\mathrm{z}} \mathrm{Bt}$ \\
\hline & None & None & $\ldots$ & $\mathrm{AgrEvo}^{z}$ non-Bt \\
\hline
\end{tabular}

${ }^{\mathrm{t}}$ As indicated by supplier.

u Monsanto Co., St. Louis, MO.

${ }^{v}$ Novartis Seeds, Greensboro, NC.

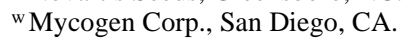

${ }^{\mathrm{x}}$ Hybrid with naturally occurring resistance to European corn borer.

y DeKalb Plant Genetics, DeKalb, IL.

${ }^{\text {z }}$ Agrevo USA Co., Apple Valley, MN. verticillioides strain M-8114 (Pennsylvania State University Fusarium Research Center, originally isolated in Iowa) on carnation-leaf agar (19) for 7 days, then scraping the contents of four CLA cultures into 500$\mathrm{ml}$ bottles containing approximately 33,000 larvae. The contents were thoroughly mixed by hand before applying to the plants as already described. For the Manual-F2 treatment, five third-instar larvae were placed in 10-ml plastic beakers and lightly misted with a suspension of strain M-8114 conidia (approximately $10^{5} / \mathrm{ml}$ ) in sterile water. One beaker was immediately placed into the axil of the ear shank of each of five plants per subplot at growth stage R1. Surface contamination of the larvae in the F1 and F2 treatments with F. verticillioides was confirmed by placing 50 neonatal larvae or five third-instar larvae on Nash-Snyder Medium (19). F. verticillioides was isolated from 60 to $75 \%$ of neonatal and $100 \%$ of third-instar larvae, compared with 5 to $10 \%$ of the larvae that were not intentionally contaminated.

After the plants reached maturity (kernel moisture of approximately 20\%) in 1995 and 1996, 10 arbitrarily selected ears per plot were visually evaluated in the field for Fusarium ear rot and insect feeding on kernels. In 1997, five ears per subplot were hand-harvested and evaluated in the laboratory. For each ear, the numbers of kernels with symptoms of Fusarium ear rot and insect feeding were recorded. Incidences of Fusarium ear rot and insect feeding were calculated as the percentages of plants per plot with symptoms. Severity of Fusarium ear rot and insect feeding were calculated as the mean number of kernels per ear with symptoms. In 1995, insect feeding was recorded in a different way; a 0 to 3 scale was used in which $0=$ no damage, $1=\leq 5$ $\mathrm{cm}^{2}$ of damage per ear, $2=>5 \leq 10 \mathrm{~cm}^{2}$ of damage per ear, and $3=>10 \mathrm{~cm}^{2}$ of damage per ear. Incidence and severity calculations were done as in the other years. The number of ECB larvae found on each plant also was recorded after splitting the stalks

Table 2. $P$ values for the effects of hybrid brand, presence of cry gene, and European corn borer (ECB) infestation on fumonisin concentrations in kernels for field experiment near Ames, Iowa, in 1996

\begin{tabular}{lcc}
\hline Effect & $\begin{array}{c}\text { Fumonisin } \\
\mathbf{B}_{\mathbf{1}}\end{array}$ & $\begin{array}{c}\text { Total } \\
\text { fumonisins }\end{array}$ \\
\hline Brand & 0.0001 & 0.0001 \\
cry gene $^{\mathrm{y}}$ & 0.0002 & 0.0003 \\
ECB infestation $^{\mathrm{z}}$ & 0.0001 & 0.0001 \\
Block $_{\text {Brand } \times \text { cry gene }}$ & 0.0026 & 0.0014 \\
Brand $\times$ ECB & 0.0065 & 0.0061 \\
cry gene $\times$ ECB & 0.0798 & 0.0606 \\
Brand $\times$ cry gene & 0.0008 & 0.0003 \\
$\quad \times$ ECB & 0.0141 & 0.0112 \\
\end{tabular}

y Effect of presence of cry gene.

${ }^{z}$ Plants were either manually infested with 50 neonatal ECB larvae (growth stages V8 to V10 and R1) or naturally infested. 
and ear shanks longitudinally and examining these tissues for larvae.

In 1995 and 1996, 30 ears per plot were hand-harvested (including the ears evaluated for disease and insect feeding), and the kernels were removed by hand or by an electric sheller. Symptomless infection was determined by culturing 50 arbitrarily selected symptomless kernels (surface-disinfested for $3 \mathrm{~min}$ in a $0.5 \%$ solution of sodium hypochlorite) from each plot on Nash-Snyder medium (NSM) (19). In 1995 and 1996, Fusarium colonies were identified after 7 to 10 days by colony and conidial morphology (19). Colonies were not identified to species in 1995 and 1996 but were classified into groups of Fusarium spp., and the percentage of kernels (incidence) infected with each group was recorded. In 1997, after the five ears harvested from each subplot had been evaluated for ear rot and insect feeding severity, they were shelled with an electric sheller, and 25 symptomless kernels per subplot were cultured on NSM. From five infected kernels per subplot, a single colony was transferred from NSM to carnation leaf agar (CLA) and identified to species according to the keys and descriptions of Nelson et al. (19). Incidence of infection by each species was recorded.

In 1995 and 1996, a 0.6-kg sample was collected arbitrarily from the shelled kernels from each plot and ground in a Wiley mill with a 2-mm mesh screen. In 1997, after the 25-kernel sample was removed and cultured, the remainder of the kernels was ground for fumonisin analysis. The ground maize was thoroughly mixed, and 10-g samples were taken for analysis of fumonisin $\mathrm{B}_{1}$ in 1995 by the procedure of Hopmans and Murphy (9) and of fumonisins $\mathrm{B}_{1}, \mathrm{~B}_{2}$, and $\mathrm{B}_{3}$ (total fumonisins) in 1996 and 1997 by the procedure of Rice et al. (21). Briefly, 10-g samples were extracted with $50 \mathrm{ml}$ of $50 \%$ acetonitrile (ACN) for at least $30 \mathrm{~min}$. The supernatant was filtered through filter paper, and $2 \mathrm{ml}$ of the filtered extract was diluted with $6 \mathrm{ml}$ of $1 \%$ potassium chloride $(\mathrm{KCl})$. The diluted sample was then cleaned up using a 500-mg $\mathrm{C}_{18}$ solid-phase extraction (SPE) column (Waters/Millipore, Milford, MA) by rinsing with $1 \mathrm{ml}$ of $1 \% \mathrm{KCl}$ and $3 \mathrm{ml}$ of $15 \% \mathrm{ACN}$. The fumonisins were then eluted using $2 \mathrm{ml}$ of $70 \%$ ACN. Fluorescent derivatives of the fumonisins were formed using $o$-phthaldialdehyde (OPA) and detected using a fluorescence detector (LC-240, Perkin-Elmer, Norwalk, CT) with an excitation wavelength of $335 \mathrm{~nm}$ and an emission wavelength of $440 \mathrm{~nm}$. Derivatization was accomplished at room temperature using a $0.25-\mathrm{ml}$ sample, 0.25 $\mathrm{ml}$ of borate buffer, $(\mathrm{pH} 8.3), 0.25 \mathrm{ml}$ of OPA solution (15 mg of OPA and $20 \mu \mathrm{l}$ of 2-mercaptoethanol in $10 \mathrm{ml}$ of $\mathrm{ACN}$ ), and $0.25 \mathrm{ml}$ water. Reaction time was $10 \mathrm{~min}$.
Ten microliters of derivatized sample ( 0.5 $\mathrm{mg}$ equivalent) was injected into a $3 \mathrm{~cm} \times$ $4.6 \mathrm{~mm}$ high speed, $3 \mu \mathrm{m}$ packing material, $\mathrm{C}_{18}$ column (Perkin-Elmer) with quantitation made using external standards and peak height measurements. Fumonisin $\mathrm{B}_{1}$ and $\mathrm{B}_{2}$ standards were purchased from Sigma Chemical Co. (St. Louis, MO), and fumonisin $\mathrm{B}_{3}$ standard was obtained from Ron Plattner (USDA-ARS, NCAUR, Peoria, IL). Detection limits were $0.1 \mu \mathrm{g} / \mathrm{g}$ for fumonisin $B_{1}$ and $0.5 \mu \mathrm{g} / \mathrm{g}$ for fumonisins $\mathrm{B}_{2}$ and $\mathrm{B}_{3}$.

Analysis of variance (SAS, Cary, NC, or SigmaStat, Jandel Scientific, San Diego, CA) was utilized to evaluate insect feeding severity, numbers of ECB larvae, Fusarium ear rot severity, incidence of symptomless infection, fumonisin $\mathrm{B}_{1}$ concentration, and total fumonisin concentration. A factorial

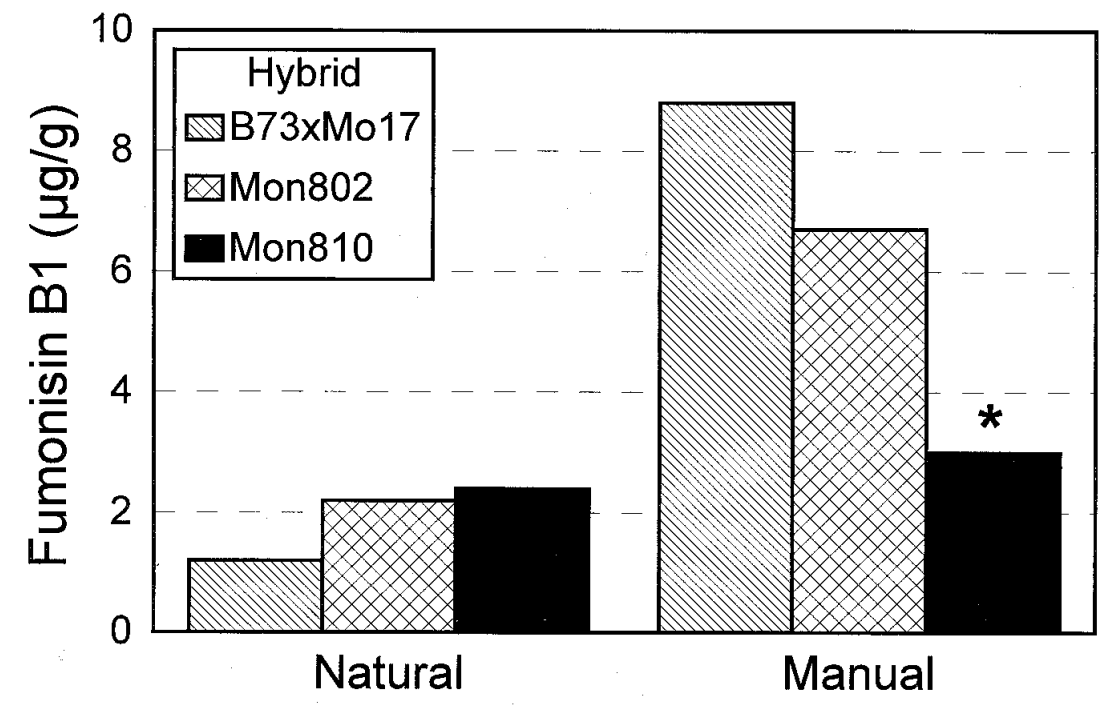

\section{Infestation}

Fig. 1. Fumonisin $B_{1}$ concentrations in kernels of transgenic Bt maize hybrids (Mon802 and Mon810) and a near-isogenic standard hybrid (B73×Mo17) in 1995. Manually infested plants were infested with 50 neonatal European corn borer (Ostrinia nubilalis) larvae at growth stages V8 to V10 and R1. * indicates a significant difference $(P \leq 0.05)$ between standard and transgenic hybrid.

Table 3. $P$ values for the effects of hybrid brand, presence of cry gene, and European corn borer (ECB) infestation on Fusarium kernel rot incidence, Fusarium ear rot severity, and incidence of symptomless kernel infection by Fusarium spp. in a field experiment in Boone County, Iowa, in 1997

\begin{tabular}{|c|c|c|c|c|c|c|c|c|c|c|}
\hline \multirow[b]{2}{*}{ Effect } & \multicolumn{2}{|c|}{ Insect feeding } & \multicolumn{2}{|c|}{ Fusarium ear rot } & \multicolumn{4}{|c|}{ Symptomless Fusarium infection ${ }^{v}$} & \multicolumn{2}{|c|}{ Fumonisin concentration } \\
\hline & Incidence $^{w}$ & Severity $^{\mathrm{x}}$ & Incidence $^{w}$ & Severity ${ }^{x}$ & Total & F. vert. & F. prol. & F. subg. & $\mathbf{F B}_{1}$ & Total \\
\hline Brand & 0.0001 & 0.0001 & 0.0001 & 0.0001 & 0.0001 & 0.0001 & 0.0003 & 0.0189 & 0.5145 & 0.5684 \\
\hline cry gene ${ }^{y}$ & 0.0001 & 0.0001 & 0.0001 & 0.0001 & 0.0001 & 0.0001 & 0.1188 & 0.2815 & 0.0001 & 0.0001 \\
\hline ECB infestation ${ }^{z}$ & 0.1300 & 0.0989 & 0.0040 & 0.0019 & 0.0001 & 0.0001 & 0.8722 & 0.0001 & 0.0001 & 0.0001 \\
\hline Block & 0.1149 & 0.0016 & 0.2693 & 0.0079 & 0.0003 & 0.0001 & 0.7183 & 0.1943 & 0.0152 & 0.0128 \\
\hline Brand $\times$ cry gene & 0.0001 & 0.0001 & 0.0001 & 0.0001 & 0.0001 & 0.0001 & 0.0120 & 0.0908 & 0.0001 & 0.0001 \\
\hline Brand $\times \mathrm{ECB}$ & 0.8711 & 0.2805 & 0.1352 & 0.3543 & 0.0051 & 0.0077 & 0.1536 & 0.3557 & 0.9550 & 0.9419 \\
\hline cry gene $\times$ ECB & 0.3668 & 0.2739 & 0.0322 & 0.0482 & 0.4020 & 0.5560 & 0.4382 & 0.2786 & 0.0338 & 0.0345 \\
\hline Brand $\times$ cry gene & 0.8586 & 0.2812 & 0.4718 & 0.2728 & 0.4261 & 0.4578 & 0.1545 & 0.5433 & 0.7115 & 0.6732 \\
\hline
\end{tabular}

\footnotetext{
$\times$ ECB
}

\footnotetext{
${ }^{\mathrm{v}}$ Measured as the percentage of infected kernels, based on isolation from 10 replications of 25 kernels each. F. verticillioides, F. proliferatum, and F. subglutinans.

${ }^{\mathrm{w}}$ Measured as the percentage of plants with symptoms, based on 10 replications of five plants each.

${ }^{x}$ Measured as the mean number of kernels with symptoms per ear, based on 10 replications of five plants each.

${ }^{y}$ Effect of presence of cry gene.

${ }^{\mathrm{z}}$ There were four infestation treatments: natural ECB infestation, manual infestation, or manual infestation with $F$. verticillioides contamination at growth stage V8 to V10 or R1.
} 
analysis was used to evaluate the main effects and interactions of hybrid brand, presence of cry genes, and ECB infestation treatment. Multiple comparison tests were performed according to the Student-Newman-Keuls test on treatment means if there were interactions. A square-root-squareroot transformation was used to obtain a normal distribution for the fumonisin data. Linear correlation coefficients were calculated for the relationships among severity of Fusarium ear rot, insect feeding severity, and fumonisin concentration (SigmaStat), using data from individual experimental units.

\section{RESULTS}

Hybrid brand, presence of cry genes, and insect infestation treatments had effects on fumonisin $\mathrm{B}_{1}$ and total fumonisin concentrations, and the significance of these effects differed among years. In 1995, when only one brand was included, the main effect of hybrid on fumonisin $B_{1}$ concentration was not significant $(P=0.240)$, but infestation had a significant effect $(P=$ $0.032)$ and there was a significant interaction $(P=0.044)$. In 1996, effects of hybrid brand, presence of cry genes, and infestation treatment were significant, but there were significant two-way and three-way interactions (Table 2). In 1997, the significant main effects were those of cry gene presence and infestation treatment, and there were significant two-way interactions (Table 3). Fumonisin concentrations were significantly lower in some transgenic hybrids compared with their nontransgenic counterparts, and fumonisin concentrations were enhanced when maize plants were manually infested with ECB larvae (Figs. 1 to 3). Significant differences among hybrids were more evident under manual infestation. In 1997, the fumonisin concentrations were higher than in the other 2 years, and the differences between transgenic and nontransgenic hybrids were most dramatic. Transgenic hybrids in some cases had concentrations less than $10 \%$ of their nontransgenic counterparts. The ManualF1 treatment resulted in the highest fumonisin concentrations in 1997, with a mean of $17.3 \mu \mathrm{g} / \mathrm{g}$ (total fumonisins), compared with $12.1 \mu \mathrm{g} / \mathrm{g}$ in the Manual-F2 treatment, $11.3 \mu \mathrm{g} / \mathrm{g}$ in the manually infested treatment, and $7.8 \mu \mathrm{g} / \mathrm{g}$ in the naturally infested treatment. Fumonisin $B_{1}$ accounted for approximately $70 \%$ of the total fumonisins, and ANOVA on total fumonisins yielded results almost identical to those for fumonisin $\mathrm{B}_{1}$.

In all 3 years, presence of $c r y$ genes had a significant $(P \leq 0.0001)$ effect on insect feeding severity on ears, with lower severity in transgenic hybrids than in nontransgenic hybrids (Tables 4 and 5). In 1996, the effects of hybrid brand and the presence of cry genes were significant $(P \leq 0.0001)$, but there also were significant two-way and three-way interactions $(P \leq 0.05)$.
Insect infestation had a significant effect on feeding severity in $1996(P \leq 0.0001)$ but not in 1995 and $1997(P=0.8235$ in 1995 and $P=0.0989$ in 1997). Significantly more larvae were found in naturally infested plants than in manually infested plants $(P=0.0043$ in 1995 and $P=0.0277$ in 1996) (Tables 4 and 5). Numbers of larvae were affected significantly by hybrid brand and presence of cry genes (transgenic hybrids had fewer larvae than nontransgenic hybrids) (Tables 4 and 5), and there was a significant $(P=0.001)$ interaction between these two factors.

Fusarium ear rot severity was affected by hybrid brand, presence of cry genes, and ECB infestation $(P \leq 0.0001)$, but there were significant interactions among these factors (17; Table 6). Generally, symptoms were less for transgenic hybrids than for nontransgenic, and less for natural infestation than for manual infestation, but these effects depended on the hybrid brand. In 1997, the second-generation manual infestation treatment that included $F$. verticillioides contamination (Manual-F2) had the highest ear rot severity (Table 6).

Incidence of symptomless kernel infection by Fusarium spp. was significantly affected by hybrid brand, presence of cry genes, and infestation treatment; there also were significant two-way interactions (17; Table 6). Transgenic hybrids had lower incidence of symptomless infection $(43.4 \%$ in 1997) than nontransgenic hybrids (53.5\% in 1997), but the difference depended on hybrid brand and infestation treatment. In 1997, the Manual-F1 treatment resulted in the highest incidence of symptomless infection in 11 of 12 hybrids

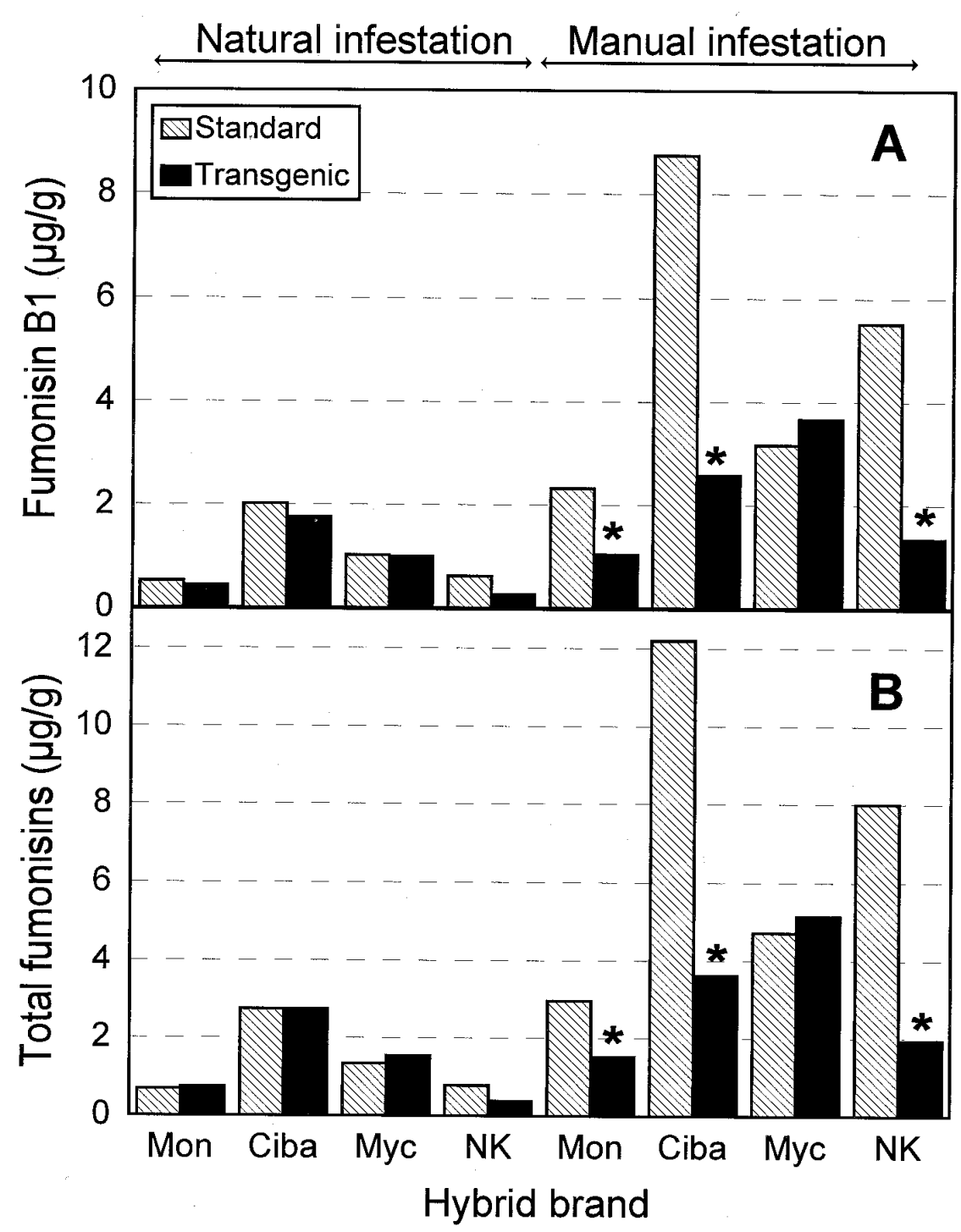

Fig. 2. Fumonisin $B_{1}$ (A) and total fumonisin (B) concentrations in kernels of transgenic $B t$ maize hybrids and near-isogenic standard hybrids in 1996. Transgenic hybrids are paired with their nearisogenic counterparts. Manually infested plants were infested with 50 neonatal European corn borer (Ostrinia nubilalis) larvae at growth stages V8 to V10 and R1. Hybrids are identified by brand: Mon (Monsanto), Ciba (Novartis), Myc (Mycogen), NK (Novartis). * indicates a significant difference $(P$ $\leq 0.05$ ) between standard and transgenic hybrids. 
(Table 6). Three species, F. verticillioides, $F$. proliferatum, and $F$. subglutinans, accounted for $99.0 \%$ of the Fusarium colonies identified from symptomless infected kernels. F. verticillioides comprised the majority $(81.4 \%)$ of the Fusarium colonies identified from all treatments. Analysis of variance on individual species indicated that incidence of infection by $F$. verticillioides was higher in the manual ECB infestation treatments than in the natural infestation treatment, but incidence of the other two species was either the same or lower in the manual infestations than in the natural infestation.

In 1996 and 1997, insect feeding severity, Fusarium ear rot severity, and incidence of symptomless infection were significantly correlated with fumonisin $\mathrm{B}_{1}$ concentration (Fig. 4). In 1995, fumonisin $B_{1}$ concentrations were significantly correlated only with incidence of symptomless infection.

\section{DISCUSSION}

Under some conditions, transgenic maize hybrids expressing cry genes from
B. thuringiensis can contain lower concentrations of fumonisins than do nontransgenic hybrids. These lower concentrations were associated with earlier-reported reductions in Fusarium ear rot and/or symptomless infection (17) that, in turn, can be attributed to reduced insect feeding on kernels of transgenic hybrids. This finding indicates that the safety of maize for human and animal consumption may be enhanced by genetic engineering for insect resistance. The magnitude of the differences in fumonisin concentrations between transgenic and nontransgenic hybrids was sufficient to affect the toxicity of these maize kernels to horses (15) and to human cell cultures $(1,23,26)$. The fumonisin concentrations that occurred in some nontransgenic hybrids were high enough to be considered unsafe for some animal species and inadvisable for human consumption. The American Association of Veterinary Laboratory Diagnosticians (AAVLD) has recommended that feeds for horses contain less than $5 \mu \mathrm{g}$ of fumonisins per $\mathrm{g}$ and that feeds for swine contain less than $10 \mu \mathrm{g}$ of fumonisins per $g$ (15). One or both of these criteria were exceeded by nontransgenic hybrids in all 3 years. There are no widely accepted standards regarding safe fumonisin concentrations for human consumption.

The hybrid brand $\times$ cry gene interaction is important in the analysis of our results because it indicates whether $\mathrm{Bt}$ transformation events differ in their effects on the dependent variables that we measured. The transgenic hybrids included in the 1996 and 1997 experiments are the products of different transformation events, so they differ either in the gene promoter or the Cry protein. Directly comparing data from different transgenic hybrids is problematic because the background Fusarium susceptibility of the hybrids differs and the effects of background genetics cannot be separated from the effects of the transgenes. By examining the hybrid brand $x$ cry gene interactions, we can assess how different transformation events affected the Fusarium ear rot, Fusarium infection, and fumonisin concentrations of their respective background hybrids. These interactions were
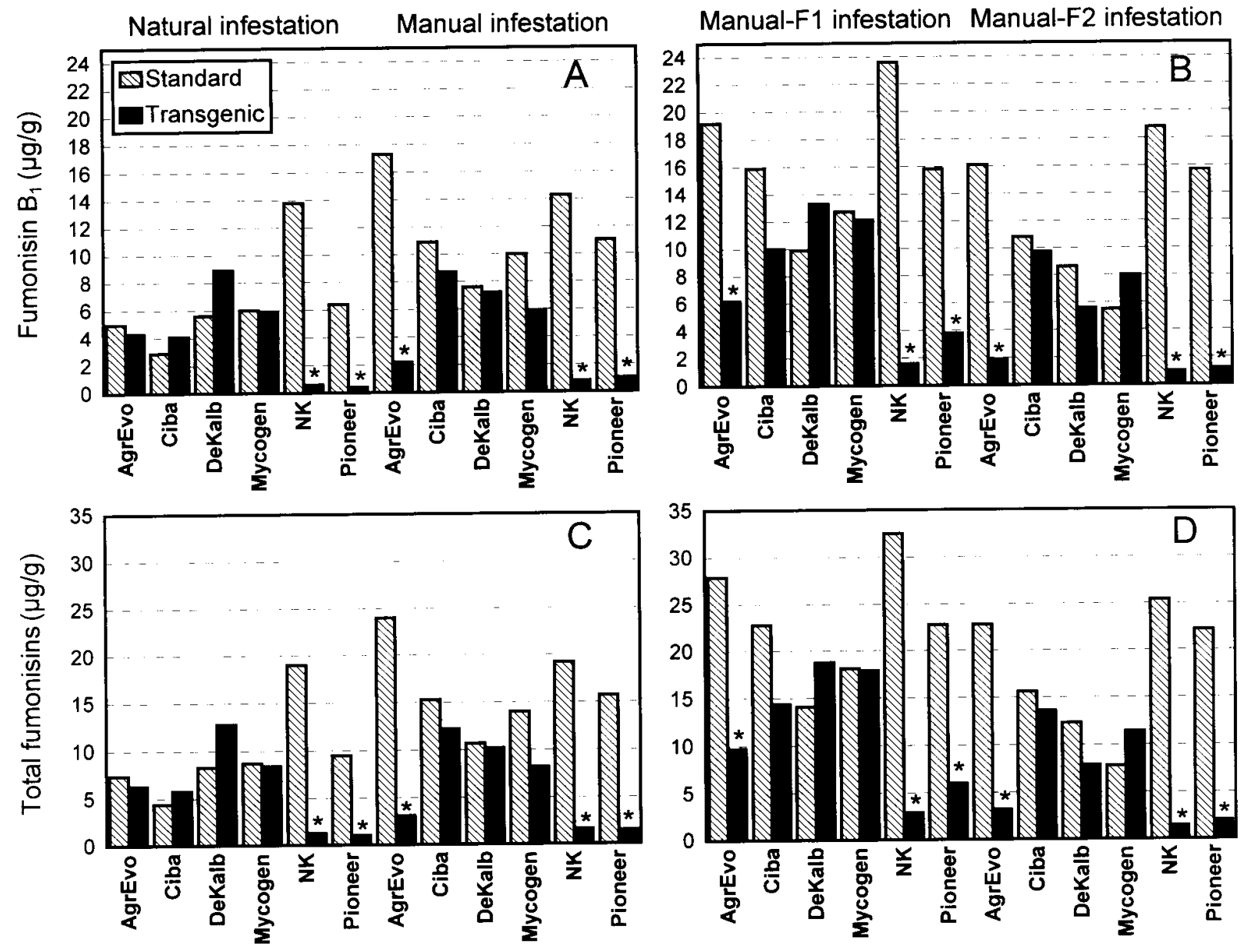

Hybrid brand

Fig. 3. Fumonisin $B_{1}$ (A and B) and total fumonisin (C and D) concentrations in kernels of transgenic Bt maize hybrids and near-isogenic standard hybrids in 1997. Transgenic hybrids are paired with their near-isogenic counterparts. Manually infested plants were infested with 50 neonatal European corn borer (Ostrinia nubilalis) larvae at growth stages V8 to V10 and R1; plants in the manual-F1 treatment were infested with 50 Fusarium verticillioidescontaminated neonatal larvae at stages V8 to V10; and plants in the manual-F2 treatment were infested with five F. verticillioides-contaminated thirdinstar larvae at stage R1. Hybrids are identified by brand. * indicates a significant difference $(P \leq 0.05)$ between standard and transgenic hybrids. 
often significant, indicating that the MON810 and BT11 transformation events led to significantly greater reductions in Fusarium ear rot severity, incidence of symptomless infection, and fumonisin concentrations than did the 176 event.

The differential effects of the transformation events can be attributed to differences in cry gene expression. Maize hybrids with the MON810 or BT11 transformation types utilize a CaMV 35S gene promoter (2) that results in seasonlong expression of CryIA(b) in all plant tissues; whereas transformation 176 utilizes a combination of two maize-derived, tissue-specific promoters: a phosphoenolpyruvate carboxylase (PEPC) promoter that results in gene expression only in green plant tissues, and a pollen-specific promoter (11). Hybrids expressing
CryIA(b) in kernels were better protected against Fusarium infection than those expressing the protein only in green tissues and pollen. This trend was evident but not universal. Hybrids with the MON810 and BT11 transformation events consistently demonstrated significant reductions in Fusarium infection and fumonisin concentration in the manual infestation treatments. Although hybrid Mon802 also expresses CryIA(b) in kernels, it did not exhibit reduced fumonisin concentration. This hybrid expresses lower concentrations of CryIA(b) than Mon810 (5), and the lower expression in this hybrid may not have controlled insect feeding on kernels sufficiently to affect fumonisin concentrations. Insect feeding severity for this hybrid was higher than, but not significantly different from, insect feeding severity for
Mon810. Therefore, the difference in fumonisin $\mathrm{B}_{1}$ concentration between these two hybrids cannot be explained completely with the available data. Hybrids with the 176 transformation event do not have kernel expression of CryIA(b) and did not consistently demonstrate effects on Fusarium ear rot or fumonisins. Ciba hybrid Max454 demonstrated significantly less Fusarium ear rot in 1996 and 1997 and lower fumonisin concentrations in 1996 than its nontransgenic counterpart, 4494, but the Mycogen transgenic hybrid did not exhibit any significant reductions in any of the variables in the manual infestation treatment. This result might have been due to differences in the genetic backgrounds of the hybrids; the nontransgenic Mycogen hybrid is known to have native resistance to $O$. nubilalis. The DBT418 transforma-

Table 4. Insect feeding severity on maize ears and European corn borer (ECB) larvae per plant in transgenic (Bt) and nontransgenic hybrids in field experiments conducted in 1995 and $1996^{\mathrm{v}}$

\begin{tabular}{|c|c|c|c|c|c|c|c|}
\hline \multirow[b]{2}{*}{ Year } & \multirow[b]{2}{*}{ Hybrid } & \multicolumn{3}{|c|}{ Insect feeding severity $^{w}$} & \multicolumn{3}{|c|}{ ECB larvae /plant ${ }^{\mathrm{x}}$} \\
\hline & & Natural & Manual $^{\mathbf{y}}$ & Mean & Natural & Manual $^{\mathbf{y}}$ & Mean \\
\hline \multirow[t]{4}{*}{1995} & $\mathrm{~B} 73 \times \mathrm{Mo} 17$ & $0.7 \mathrm{a}$ & $0.7 \mathrm{a}$ & 0.7 & $1.17 \mathrm{a}$ & $0.42 \mathrm{~b}$ & 0.79 \\
\hline & Mon $802 * z$ & $0.2 \mathrm{~b}$ & $0.3 \mathrm{~b}$ & 0.2 & $0.02 \mathrm{c}$ & $0.00 \mathrm{c}$ & 0.01 \\
\hline & Mon $810^{*}$ & $0.1 \mathrm{~b}$ & $0.1 \mathrm{~b}$ & 0.1 & $0.00 \mathrm{c}$ & $0.00 \mathrm{c}$ & 0.00 \\
\hline & Means & 0.3 & 0.4 & 0.3 & 0.40 & 0.14 & 0.27 \\
\hline \multirow[t]{9}{*}{1996} & Mon $810^{*}$ & $0.5 \mathrm{ef}$ & $0.2 \mathrm{f}$ & 0.3 & $0.00 \mathrm{f}$ & $0.00 \mathrm{f}$ & 0.00 \\
\hline & B73 $\times$ Mo17 & $2.2 \mathrm{def}$ & $2.3 \mathrm{def}$ & 2.2 & $1.02 \mathrm{a}$ & $0.86 \mathrm{abc}$ & 0.96 \\
\hline & Ciba MAX454* & $3.0 \mathrm{cde}$ & $2.3 \mathrm{def}$ & 2.6 & $0.16 \mathrm{ef}$ & $0.10 \mathrm{f}$ & 0.13 \\
\hline & Ciba 4494 & $5.1 \mathrm{bc}$ & $12.3 \mathrm{a}$ & 8.7 & $0.94 \mathrm{ab}$ & $0.80 \mathrm{abc}$ & 0.87 \\
\hline & Mycogen NG7059BT* & $3.3 \mathrm{~cd}$ & $7.1 \mathrm{~b}$ & 5.2 & 0.52 cde & 0.20 def & 0.36 \\
\hline & Mycogen 7050cb & $6.3 \mathrm{~b}$ & $7.6 \mathrm{~b}$ & 6.9 & $0.78 \mathrm{abc}$ & 0.52 cde & 0.66 \\
\hline & Northrup King X6534CBR* & $0.8 \mathrm{def}$ & 0.4 ef & 0.6 & $0.00 \mathrm{f}$ & $0.00 \mathrm{f}$ & 0.00 \\
\hline & Northrup King N6800 & $2.0 \mathrm{def}$ & $7.0 \mathrm{~b}$ & 4.5 & $0.58 \mathrm{bc}$ & $0.54 \mathrm{~cd}$ & 0.56 \\
\hline & Means & 2.9 & 4.9 & 3.9 & 0.50 & 0.38 & 0.44 \\
\hline
\end{tabular}

${ }^{\mathrm{v}}$ Near-isogenic hybrids are paired in the table. Values are means for six replications of 10 ears in 1995 and five replications of 10 ears in 1996. Values within a year followed by the same letter are not significantly different (Student-Newman-Keuls test, $\alpha=0.05$ ).

${ }^{\mathrm{w}}$ Insect feeding severity was assessed on a 0 to 3 scale in 1995 and as the mean number of damaged kernels per plant in 1996 (10 plants per plot).

${ }^{x}$ Numbers of live and dead ECB larvae in the ears, stalks, and shanks were recorded at harvest maturity (10 plants per plot).

${ }^{\mathrm{y}}$ Manual infestation consisted of 50 neonatal ECB larvae placed in the whorl at stage V8 to V10 and in the axil of the ear leaf at stage R1.

$\mathrm{z} *=$ Bt hybrids.

Table 5. Insect feeding severity on maize ears in transgenic (Bt) and nontransgenic hybrids in a field experiment conducted in 1997u

\begin{tabular}{|c|c|c|c|c|c|c|}
\hline \multirow[b]{2}{*}{ Year } & \multirow[b]{2}{*}{ Hybrid } & \multicolumn{5}{|c|}{ Insect feeding severity $^{v}$} \\
\hline & & Natural & Manual $^{w}$ & Manual-F1 $^{x}$ & Manual-F2 ${ }^{\mathbf{y}}$ & Mean \\
\hline \multirow[t]{13}{*}{1997} & Pioneer hybrid 34R06*z & 0.5 & 0.7 & 1.7 & 1.3 & $1.0 \mathrm{e}$ \\
\hline & Pioneer hybrid 3489 & 12.8 & 15.7 & 16.0 & 22.6 & $16.8 \mathrm{bc}$ \\
\hline & Novartis NK 7070BT* & 0.7 & 0.3 & 0.7 & 1.3 & $0.7 \mathrm{e}$ \\
\hline & Novartis NK 7070 & 17.1 & 20.8 & 19.9 & 20.6 & $19.6 \mathrm{~b}$ \\
\hline & Mycogen NG 7059* & 11.7 & 13.6 & 13.4 & 12.6 & $12.8 \mathrm{~cd}$ \\
\hline & Mycogen 7059cb & 14.9 & 15.1 & 16.3 & 11.6 & $14.5 \mathrm{~cd}$ \\
\hline & Ciba Max 454* & 9.9 & 11.4 & 8.7 & 13.4 & $10.8 \mathrm{~d}$ \\
\hline & Ciba 4494 & 15.3 & 22.1 & 17.6 & 20.0 & $18.7 \mathrm{~b}$ \\
\hline & DeKalb 580BT* & 9.7 & 11.1 & 13.2 & 9.3 & $10.8 \mathrm{~d}$ \\
\hline & DeKalb 580 & 18.9 & 15.8 & 13.1 & 14.5 & $15.6 \mathrm{bc}$ \\
\hline & AgrEvo Bt* & 4.4 & 3.1 & 1.9 & 2.3 & $2.9 \mathrm{e}$ \\
\hline & AgrEvo & 28.3 & 34.2 & 26.1 & 36.7 & $31.3 \mathrm{a}$ \\
\hline & Means & 12.0 & 13.7 & 12.4 & 13.9 & 13.0 \\
\hline
\end{tabular}

u Near-isogenic hybrids are paired in the table. Values are means for 10 replications of five ears. Values followed by the same letter are not significantly different (Student-Newman-Keuls test, $\alpha=0.05$ ).

${ }^{\mathrm{v}}$ Insect feeding severity was assessed as the mean number of damaged kernels per plant in 1997 (five ears per plot).

${ }^{w}$ Manual infestation consisted of 50 neonatal European corn borer (ECB) larvae placed in the whorl at stage V8 to V10 and in the axil of the ear leaf at stage R1.

${ }^{x}$ Manual-F1 treatment consisted of 50 neonatal ECB larvae contaminated with Fusarium verticillioides conidia and placed in the whorl at stage V8 to V10.

${ }^{y}$ Manual-F2 treatment consisted of five third-instar ECB larvae contaminated with F. verticillioides conidia and placed in the ear shank axil at stage R1.

$\mathrm{z} *=$ Bt hybrids. 
tion event demonstrated results similar to the 176 event, and the $\mathrm{CBH} 351$ event demonstrated results similar to the MON810 event, but we have only 1 year of data for DBT418 and CBH351.
Fumonisin concentrations were significantly correlated with insect feeding severity, Fusarium ear rot, and symptomless Fusarium infection in 1996 and 1997, but only with symptomless infection in 1995.
Symptomless infection occurs by a number of pathways that may or may not be related to insect feeding (18). Typically, fumonisin concentrations are higher in symptomatic kernels (6), and Fusarium ear rot severity

Table 6. Fusarium ear rot severity and symptomless kernel infection in Bt and non-Bt hybrids subjected to manual and natural infestations of European corn borer (ECB) in Boone County, Iowa, in 1997u

\begin{tabular}{|c|c|c|c|c|c|c|c|c|c|c|c|}
\hline \multirow[b]{2}{*}{ Brand } & \multirow[b]{2}{*}{ Hybrid } & \multicolumn{5}{|c|}{ Fusarium ear rot severity (kernels/ear) } & \multicolumn{5}{|c|}{ Symptomless infection (\% of kernels) } \\
\hline & & Manualv $^{v}$ & Manual-F1 $^{w}$ & Manual-F2x & Naturaly & Mean & Manualv $^{v}$ & Manual-F1 $^{w}$ & Manual-F2x $^{x}$ & Naturaly $^{y}$ & Mean \\
\hline AgrEvo & $\mathrm{Bt} * \mathrm{z}$ & $2.8 \mathrm{c}$ & $2.5 \mathrm{~d}$ & $3.2 \mathrm{c}$ & $4.8 \mathrm{c}$ & 3.3 & $25.9 \mathrm{~d}$ & $56.4 \mathrm{a}$ & $30.4 \mathrm{c}$ & $19.6 \mathrm{~d}$ & 33.1 \\
\hline AgrEvo & non-Bt & $38.4 \mathrm{a}$ & $23.1 \mathrm{ab}$ & $31.9 \mathrm{a}$ & $21.5 \mathrm{a}$ & 28.7 & $43.5 \mathrm{bcd}$ & $64.4 \mathrm{a}$ & $48.4 \mathrm{ab}$ & 30.2 b-e & 46.6 \\
\hline Ciba & $\operatorname{Max} 454 *$ & $10.1 \mathrm{bc}$ & $10.6 \mathrm{c}$ & $13.9 \mathrm{~b}$ & $9.2 \mathrm{bc}$ & 11.0 & $67.8 \mathrm{ab}$ & $64.4 \mathrm{a}$ & $60.0 \mathrm{ab}$ & $46.7 \mathrm{ab}$ & 59.7 \\
\hline Ciba & 4454 & $25.7 \mathrm{~b}$ & $17.6 \mathrm{bc}$ & $26.6 \mathrm{ab}$ & $14.1 \mathrm{ab}$ & 21.0 & $71.6 \mathrm{a}$ & $72.8 \mathrm{a}$ & $66.0 \mathrm{a}$ & $49.6 \mathrm{a}$ & 65.0 \\
\hline DeKalb & DK580BT* & $17.9 \mathrm{~b}$ & $19.2 \mathrm{abc}$ & $19.1 \mathrm{ab}$ & $15.7 \mathrm{ab}$ & 18.0 & $58.0 \mathrm{abc}$ & $70.0 \mathrm{a}$ & $58.4 \mathrm{ab}$ & $44.8 \mathrm{ab}$ & 57.8 \\
\hline DeKalb & DK580 & $19.8 \mathrm{~b}$ & $18.5 \mathrm{abc}$ & $18.9 \mathrm{ab}$ & $21.5 \mathrm{a}$ & 19.7 & $59.1 \mathrm{abc}$ & $73.0 \mathrm{a}$ & $61.1 \mathrm{ab}$ & $39.2 \mathrm{abc}$ & 58.1 \\
\hline Mycogen & NG7059* & $13.7 \mathrm{bc}$ & $15.9 \mathrm{bc}$ & $15.4 \mathrm{~b}$ & $13.6 \mathrm{ab}$ & 14.7 & $54.8 \mathrm{abc}$ & $65.3 \mathrm{a}$ & $54.9 \mathrm{ab}$ & 37.8 a-d & 53.2 \\
\hline Mycogen & $7050 \mathrm{cb}$ & $17.1 \mathrm{~b}$ & $18.9 \mathrm{abc}$ & $16.2 \mathrm{~b}$ & $16.2 \mathrm{ab}$ & 17.1 & $40.4 \mathrm{~cd}$ & $60.4 \mathrm{a}$ & $41.2 \mathrm{bc}$ & $28.7 \mathrm{bcd}$ & 42.7 \\
\hline NK & NK7070BT* & $2.1 \mathrm{c}$ & $2.1 \mathrm{~d}$ & $2.6 \mathrm{c}$ & $1.3 \mathrm{c}$ & 2.0 & $26.4 \mathrm{~d}$ & $39.6 \mathrm{~b}$ & $29.6 \mathrm{c}$ & $19.2 \mathrm{~d}$ & 28.7 \\
\hline NK & NK7070 & $25.1 \mathrm{~b}$ & $26.6 \mathrm{a}$ & $27.2 \mathrm{ab}$ & $20.3 \mathrm{a}$ & 24.8 & $59.6 \mathrm{abc}$ & $67.6 \mathrm{a}$ & $57.2 \mathrm{ab}$ & $53.2 \mathrm{a}$ & 59.4 \\
\hline Pioneer & 34R06* & $1.7 \mathrm{c}$ & $2.3 \mathrm{~d}$ & $2.5 \mathrm{c}$ & $0.5 \mathrm{c}$ & 1.8 & $28.4 \mathrm{~d}$ & $57.2 \mathrm{a}$ & $12.0 \mathrm{~d}$ & $13.2 \mathrm{e}$ & 27.7 \\
\hline Pioneer & 3489 & $17.4 \mathrm{~b}$ & $15.5 \mathrm{bc}$ & $26.5 \mathrm{ab}$ & $15.6 \mathrm{ab}$ & 18.8 & $56.9 \mathrm{abc}$ & $66.2 \mathrm{a}$ & $52.0 \mathrm{ab}$ & $24.0 \mathrm{~cd}$ & 49.8 \\
\hline Means & & 16.0 & 14.4 & 17.0 & 12.9 & 15.1 & 49.3 & 63.1 & 47.6 & 33.7 & 48.4 \\
\hline
\end{tabular}

u Values in a column followed by the same letter are not significantly different (Student-Newman-Keuls test, $\alpha=0.05$ ).

${ }^{v}$ Manual infestation treatment consisted of 50 neonatal ECB larvae placed in the whorl at stage V8 to V10 and in the axil of the ear leaf at stage R1.

${ }^{w}$ Manual-F1 treatment consisted of 50 neonatal ECB larvae contaminated with Fusarium verticillioides conidia and placed in the whorl at stage V8 to V10.

x Manual-F2 treatment consisted of five third-instar ECB larvae contaminated with F. verticillioides conidia and placed in the ear shank axil at stage R1.

y The natural infestation treatment consisted of the endemic ECB population.

$\mathrm{z} *=$ Bt hybrids.
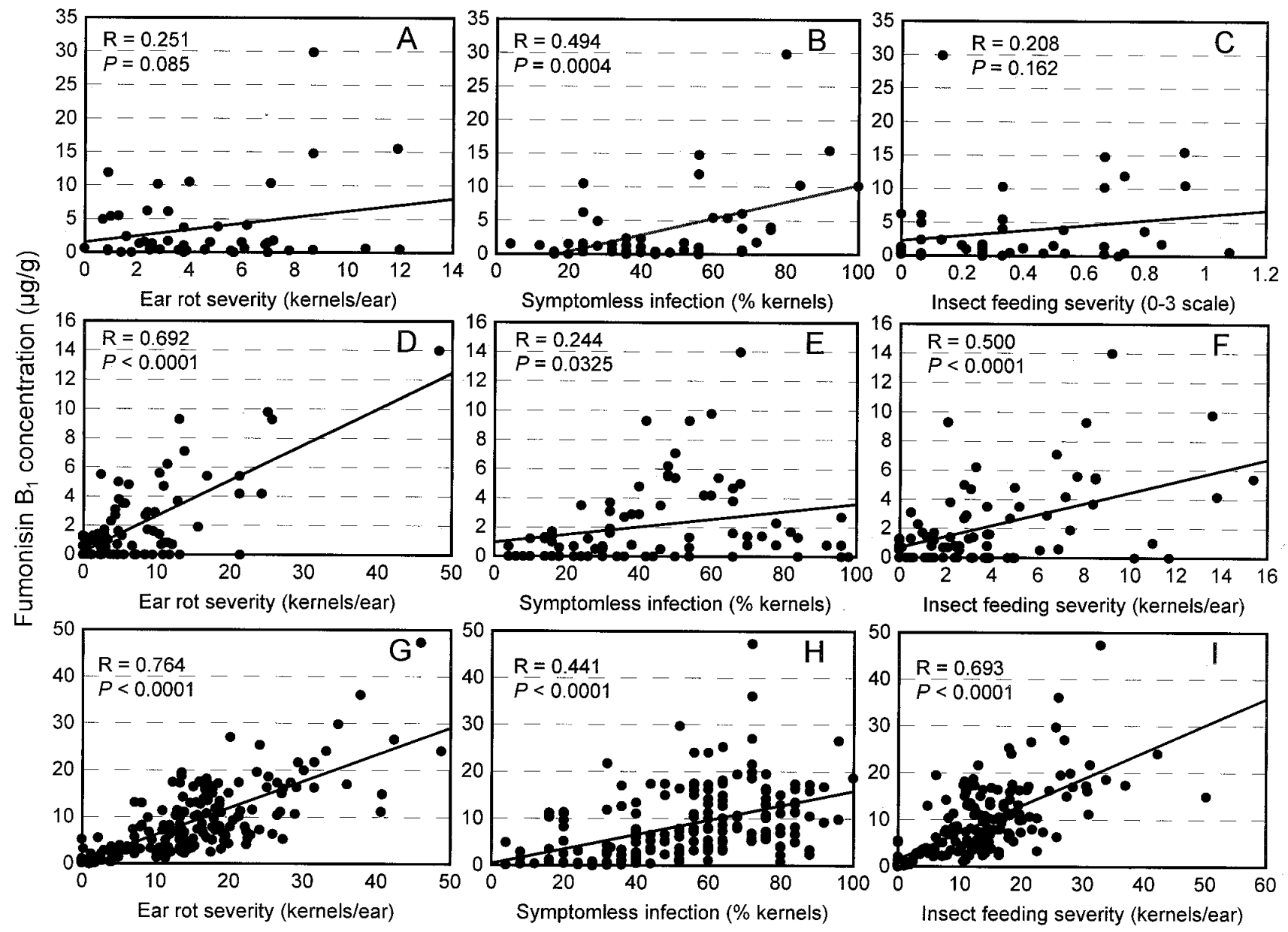

Fig. 4. Linear correlations of Fusarium ear rot severity, symptomless Fusarium infection, and insect feeding severity with fumonisin $B_{1}$ concentrations in 1995 (A to C), 1996 (D to F), and 1997 (G to I). Correlations were calculated on individual experimental units. 
is enhanced by insect feeding (18). The highest fumonisin concentrations occurred in 1997, the year in which insect feeding severity and Fusarium ear rot severity were highest. The 1996 and 1997 correlations are consistent with these relationships, but the 1995 correlations are less so. The lack of correlation between fumonisin concentrations and ear rot severity in 1995 is a result of the low fumonisin concentration in hybrid B73×Mo17 in the naturally infested compared with the manually infested treatment. Although manual infestation did not affect ear rot severity, it strongly affected fumonisin concentration. Sampling may also have affected correlation coefficients. In 1995 and 1996, Fusarium ear rot and insect feeding severity were assessed in the field on 10 ears per plot, but symptomless infection and fumonisin concentrations were analyzed on a subsample of grain harvested from each entire plot. In 1997, all assessments and analyses were performed on the same five ears per plot. As a result, correlation coefficients tended to be higher in 1997 than in 1996.

Our results also indicate that fumonisin concentrations in maize kernels can be affected by ECB infestation. Differences in Fusarium ear rot and fumonisin concentrations between transgenic and nontransgenic hybrids were evident primarily in manually infested treatments. The effect may be related to larval numbers, placement, and/or timing of infestation. Manual infestation with ECB larvae was performed in order to reduce variability in insect feeding among the plants and ensure that some viable larvae occurred on each plant. The number of larvae used (50) is a standard and realistic population for manual infestation $(6,14)$. Natural mortality of ECB larvae hatching on maize leaf surfaces is about $70 \%$ in the first instar, and 50 to $80 \%$ of the surviving larvae die before tunneling into the plant (14). The number of larvae likely to survive in the manual infestation was therefore similar to that which would occur if one egg mass were laid per plant. Manual infestation did not increase the total number of larvae recovered from plants at maturity in 1995 or 1996, nor did it affect insect feeding severity on kernels in 1995 or 1997, indicating that the number of larvae per plant was not unrealistic in the manual infestation treatment. Nevertheless, this treatment did significantly affect Fusarium ear rot and fumonisin concentrations in some hybrids. This is probably more related to the timing and placement of the infestation than to the total number of larvae. Manual second-generation infestation occurred at stage R1, and larvae were placed in the ear-leaf axil; both timing and placement were optimal for the larvae to damage the kernels at an early plant reproductive stage, allowing the maximum time for fumonisin accumulation before harvest. In 1997, the manual infestation treatments that included $F$. verticillioides inoculum resulted in the highest Fusarium ear rot severity and fumonisin concentrations, as expected.

Other mycotoxins in maize also may be affected by insect activity. Most important among these are the aflatoxins, produced primarily by Aspergillus flavus (12). Seed of transgenic $B t$ cotton sometimes have lower aflatoxin concentrations than seed of nontransgenic cotton (4), but there are no reports demonstrating a similar effect in corn kernels. This possibility warrants further study.

\section{ACKNOWLEDGMENTS}

Journal Paper J-17323 of the Iowa Agriculture and Home Economics Experiment Station, Ames, Project 3260, supported by Hatch Act and State of Iowa funds. We thank Patricia A. Murphy, Iowa State University Department of Food Science and Human Nutrition, for cooperation in performing fumonisin analysis in 1995, Gemma Castellá, Autonomous University of Barcelona, for assistance with Fusarium identification in 1997, and John Shriver for technical assistance. This research was funded, in part, by the Monsanto Co., St. Louis, MO. This is a joint contribution from USDA, Agricultural Research Service, and Iowa State University. Product names are necessary to report factually on available data; however, neither the USDA nor Iowa State University guarantees or warrants the standard of the product, and the use of the names implies no approval of the product to the exclusion of others that may be suitable.

\section{LITERATURE CITED}

1. Abbas, H. K., Tanaka, T., and Shier, W. T. 1995. Biological activities of synthetic analogues of Alternaria alternata toxin (AALtoxin) and fumonisin in plant and mammalian cell cultures. Phytochemistry 40:1681-1689.

2. Armstrong, C. L., Parker, G. B., Pershing, J. C., Brown, S. M., Sanders, P. R., Duncan, D. R., Stone, T., Dean, D. A., DeBoer, D. L., Hart, J., Howe, A. R., Morrish, F. M., Pajeau, M. E., Petersen, W. L., Reich, B. J., Rodriguez, R., Santino, C. G., Sato, S. J., Schuler, W., Sims, S. R., Stehling, S., Tarochione, L. J., and Fromm, M. E. 1995. Field evaluation of European corn borer control in progeny of 173 transgenic corn events expressing an insecticidal protein from Bacillus thuringiensis. Crop Sci. 35:550-557.

3. Christensen, J. J., and Schneider, C. L. 1950. European corn borer (Pyrausta nubilalis Hbn.) in relation to shank, stalk, and ear rots of corn. Phytopathology 40:284-291.

4. Cotty, P. J., Howell, D. R., Bock, C., and Tellez, A. 1997. Aflatoxin contamination of commercially grown transgenic BT cottonseed. Pages 108-110 in: Proc. Beltwide Cotton Prod. Res. Conf. National Cotton Council of America, Memphis, TN.

5. Davis, P. M., and Coleman, S. B. 1997. European corn borer (Lepidoptera: Pyralidae) feeding behavior and survival on transgenic corn containing CryIA(b) protein from $B a$ cillus thuringiensis. J. Kans. Entomol. Soc. 70:31-38.

6. Desjardins, A. E., and Plattner, R. D. 1998. Distribution of fumonisins in symptomatic and symptomless kernels of maize. Plant Dis. 82:953-958.

7. Guthrie, W. D., and Barry, B. D. 1987. Methodologies used for screening and determining resistance in maize to the European corn borer. Pages 122-129 in: Toward insect resistant maize for the Third World: Proc. Int. Sympos. Methodol. Devel. Host Plant Resist.
Maize Insects. CIMMYT, Mexico, D. F., Mexico.

8. Hofte, H., and Whiteley, H. R. 1989. Insecticidal crystal proteins of Bacillus thuringiensis. Microbiol. Rev. 53:242-255.

9. Hopmans, E. C., and Murphy, P. A. 1993. Detection of fumonisins $\mathrm{B}_{1}, \mathrm{~B}_{2}$, and $\mathrm{B}_{3}$ and hydrolyzed fumonisin $\mathrm{B}_{1}$ in corn-containing foods. J. Agric. Food Chem. 41:1655-1658.

10. International Agency for Research on Cancer (IARC). 1993. Monograph on the Evaluation of Carcinogenic Risk to Humans, 56, 445.

11. Koziel, M. G., Beland, G. L., Bowman, C., Carozzi, N. B., Crenshaw, R., Crossland, L., Dawson, J., Desai, N., Hill, M., Kadwell, S., Launis, K., Lewis, K., Maddox, D., McPherson, K., Meghji, M. R., Merlin, E., Rhodes, R., Warren, G. W., Wright, M., and Evola, S. V. 1993. Field performance of elite transgenic maize plants expressing an insecticidal protein derived from Bacillus thuringiensis. Bio/Technology 11:194-200.

12. Lillehoj, E. B., Fennell, D. I., Kwolek, W. F., Adams, G. L., Zuber, M. S., Horner, E. S. Widstrom, N. W., Warren, H., Guthrie, W. D. Sauer, D. B., Findley, W. R., Manwiller, A. Josephson, L. M., and Bockholt, A. J. 1978. Aflatoxin contamination of corn before harvest: Aspergillus flavus association with insects collected from developing ears. Crop Sci. 18:921-924.

13. Marasas, W. F. O. 1995. Fumonisins: Their implications for human and animal health. Nat. Toxins 3:193-198.

14. Mason, C. E., Rice, M. E., Calvin, D. D., Van Duyn, J. W., Showers, W. B., Hutchison, W. D., Witkowski, J. F., Higgins, R. A., Onstad, D. W., and Dively, G. P. 1996. European corn borer ecology and management. NC Regional Extension Publ. 327. Iowa State University, Ames.

15. Miller, M. A., Honstead, J. P., and Lovell, R. A. 1996. Regulatory aspects of fumonisin with respect to animal feeds. Pages 363-368 in: Fumonisins in Food. L. Jackson, J. DeVries, and L. Bullerman, eds. Plenum Press, New York.

16. Munkvold, G. P., and Desjardins, A. E. 1997. Fumonisins in maize: Can we reduce their occurrence? Plant Dis. 81:556-565.

17. Munkvold, G. P., Hellmich, R. L., and Showers, W. B. 1997. Reduced Fusarium ear rot and symptomless infection in kernels of maize genetically engineered for European corn borer resistance. Phytopathology 87:1071-1077.

18. Munkvold, G. P., McGee, D. C., and Carlton, W. M. 1997. Importance of different pathways for maize kernel infection by Fusarium moniliforme. Phytopathology 87:209-217.

19. Nelson, P. E., Toussoun, T. A., and Marasas, W. F. O. 1983. Fusarium Species: An Illustrated Manual for Identification. Pennsylvania State University, University Park.

20. Rheeder, J. P., Marasas, W. F. O., Thiel, P. G., Sydenham, E. W., Shephard, G. S., and van Schalkwyk, D. J. 1992. Fusarium moniliforme and fumonisins in corn in relation to human esophageal cancer in Transkei. Phytopathology 82:353-357.

21. Rice, L. G., Ross, P. F., DeJong, J., Plattner, R. D., and Coats, J. R. 1995. Evaluation of a liquid chromatographic method for the determination of fumonisins in corn, poultry feed, and Fusarium culture material. J. AOAC Int 78:1002-1009.

22. Ritchie, S. W., Hanway, J. J., and Benson, G. O. 1992. How a corn plant develops. Ia. State Univ. Ext. Spec. Rep. 48.

23. Shier, W. T., Abbas, W. K., and Mirocha, C. J. 1991. Toxicity of the mycotoxins fumonisin $\mathrm{B}_{1}$ and $\mathrm{B}_{2}$ and Alternaria alternata $\mathrm{f}$. sp. lycopersici toxin (AAL) in cultured mammalian 
cells. Mycopathologia 116:97-104.

24. Smith, D. R., and White, D. G. 1988. Corn diseases. Pages 687-766 in: Corn and Corn Improvement, 3rd ed. G. F. Sprague and J. W. Dudley, eds. American Society of Agronomy, Madison, WI.

25. Sobek, E. A. 1996. Associations between corn insects and symptomatic and asymptomatic corn kernel infection by Fusarium moniliforme. M.S. thesis. Iowa State University, Ames.

26. Tolleson, W. H., Melchior, W. B., Jr., Morris, S. M., McGarrity, L. J., Domon, O. E., Muskhelishrili, L., James, S. J., and How- ard, P. C. 1996. Apoptotic and antiproliferative effects of fumonisin B1 in human keratinocytes, fibroblasts, esophageal epithelial cells and hepatoma cells. Carcinogenesis 17:239-249.

27. USDA-APHIS. 1996. Veterinary Services Information Sheet 3374. 